\title{
Triactome: neuro-immune-adipose interactions. Implication in vascular biology
}

\author{
George Nikov Chaldakov ${ }^{1}{ }^{*}$, Marco Fiore $^{2}$, Peter l. Ghenev ${ }^{3}$, Jerzy Beltowski $^{4}$, Gorana Ranćić ${ }^{5}$, Neşe Tunçel $^{6}$ \\ and Luigi Aloe ${ }^{2}$
}

1 Laboratory of Cell Biology, Department of Anatomy and Histology, Medical University, Varna, Bulgaria

2 Institute of Cellular Biology and Neurobiology, National Research Council, Rome, Italy

${ }^{3}$ Department of General and Clinical Pathology, Medical University, Varna, Bulgaria

${ }^{4}$ Department of Pathophysiology, Medical University, Lublin, Poland

${ }^{5}$ Department of Histology and Embryology, University Medical Faculty, Niš, Serbia

${ }^{6}$ Department of Physiology, Medical Faculty, Eskişehir University, Eskişehir, Turkey

\section{Edited by:}

Oreste Gualillo, Santiago University Clinical Hospital, Spain

\section{Reviewed by:}

Marcia Hiriart, Universidad Nacional Autónoma de México, Mexico

Johan Renes, Maastricht University, Netherlands

*Correspondence:

George Nikov Chaldakov, Laboratory of Cell Biology, Department of Anatomy and Histology, Medical University, Varna BG-9002, Bulgaria e-mail:chaldakov@yahoo.com
Understanding how the precise interactions of nerves, immune cells, and adipose tissue account for cardiovascular and metabolic biology is a central aim of biomedical research at present. A long standing paradigm holds that the vascular wall is composed of three concentric tissue coats (tunicae): intima, media, and adventitia. However, large- and mediumsized arteries, where usually atherosclerotic lesions develop, are consistently surrounded by periadventitial adipose tissue (PAAT), we recently designated tunica adiposa (in brief, adiposa like intima, media, and adventitia). Today, atherosclerosis is considered an immunemediated inflammatory disease featured by endothelial dysfunction/intimal thickening, medial atrophy, and adventitial lesions associated with adipose dysfunction, whereas hypertension is characterized by hyperinnervation-associated medial thickening due to smooth muscle cell hypertrophy/hyperplasia. PAAT expansion is associated with increased infiltration of immune cells, both adipocytes and immunocytes secreting pro-inflammatory and anti-inflammatory (metabotrophic) signaling proteins collectively dubbed adipokines. However, the role of vascular nerves and their interactions with immune cells and paracrine adipose tissue is not yet evaluated in such an integrated way. The present review attempts to briefly highlight the findings in basic and translational sciences in this area focusing on neuro-immune-adipose interactions, herein referred to as triactome. Triactome-targeted pharmacology may provide a novel therapeutic approach in cardiovascular disease.

Keywords: adipose tissue, adipokines, atherosclerosis, lymphocytes, mast cells, NGF, BDNF, perivascular nerves
Today I want to tell you three stories from my life. That's it. No big deal. Just three stories. The first story is about connecting the dots.

Steve Jobs, from his Commencement address delivered on June 12, 2005 at the Stanford University, Stanford, CA, USA.

\section{PROLOG}

At the beginning of this century the Human Genome Project was finalized estimating over 30,000 genes encoding more than 100,000 functionally distinct proteins. As happened usually, one solved problem delivered many unsolved ones. Thus in the postgenome time, many "-ome" projects have emerged including proteome, transcriptome, interactome, metabolome, adipokinome, secretome, exposome, connectome so much numerous to be listed. Perhaps, this prompted Jeff Lichtman and Joshua Sanes to entitle one of their connectome articles Ome sweet ome [Curr Opin Neurobiol (2008) 18:346-53].

The present review is about connecting the dots from neuroimmunology, adipobiology, and vascular biology into the hypothesis of neuro-immune-adipose interactions, herein designated triactome.

\section{VASCULAR WALL}

Traditional view considers that the arterial wall is composed of three concentric tissue coats (tunicae): intima, media, and adventitia. However, in 1991, Soltis and Cassis studying rat aorta contractility wrote: "Virtually every blood vessel in the (human) body is surrounded to some degree by adipose tissue" (1). Forgotten, periadventitial adipose tissue (PAAT) has emerged again in the beginning of the 2000s (2-6). Indeed, largeand medium-sized arteries, where usually atherosclerotic lesions develop, are consistently surrounded by PAAT, recently conceptualized as fourth, outermost vascular coat, that is, tunica adiposa (hereafter also termed adiposa, like intima, media, and adventitia) (7, 8). Like epicardial adipose tissue (EAT) (9) and that around other internal organs (10), adiposa is not separated by a fascia from the underlying tissue, thus a bidirectional pathway between adiposa and other vascular coats is available for diffusible signals.

As depicted in Figure 1, the perivascular nerves are positioned at the media-adventitia border. Vascular as well as adipose tissue are extensively innervated by sympathetic nerves $(11,12)$, and their density correlates with the presence of nerve growth factor 


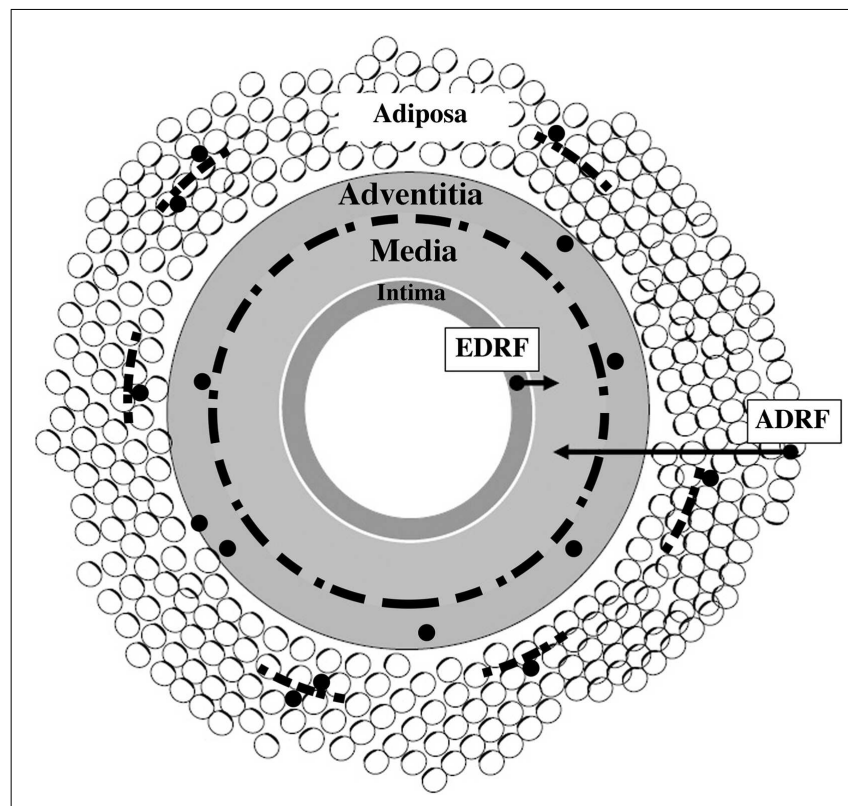

FIGURE 1 | Schematic presentation of vascular wall composed of four tissue coats (tunicae): intima, media, adventitia, and adiposa. Arrows show that tunica media is a target for at least two vasorelaxing factors, endothelium-derived relaxing factor (EDRF) and adipocyte-derived relaxing factor (ADRF), respectively. Discontinuous black line positioned at the adventitia-media border illustrates perivascular nerves. Small-sized discontinuous black lines located in tunica adiposa indicate adipose nerves. Black granules (except those linked to arrows) illustrate immune cells - their association with nerves and adipocytes is also depicted. Modified from Ref. (14).

(NGF) (see below). The artery wall has the capacity to undergo remodeling in response to long-term changes or injuries. This is a process of structural rearrangement that involves cell growth, death, migration, phenotypic modulation, and secretion of extracellular matrix molecules by secretory phenotype smooth muscle cells (SMCs) (13).

\section{VASCULAR DISEASE}

Cardiovascular disease (CVD) is the number one cause of death globally, and the major CVD's phenotypes are atherosclerosis and hypertension. The raised (occlusive) intimal lesions are classically referred to as atherosclerotic plaques.

The inflammatory nature of atherosclerotic plaques was first described by Rudolf Virchow in 1858. Onward, since 1933 Nikolai Anitchkov's lipid deposition and the 1970s Russell Ross' proliferation of SMC in response to endothelial injury (15) were dominant concepts explaining the origin and development of atherosclerosis. However, in the mid 1980s, Göran Hansson has discovered immune cells ( $\mathrm{T}$ cells and macrophages) in the human atherosclerotic plaque, hence created a paradigm shift in atherosclerosis research - the process of atherogenesis is governed by immune-mediated inflammatory mechanisms (16).

In brief, atherosclerosis is a progressive chronic lipid- and insulin resistance-driven inflammatory disease (15-19). This view however is mainly intima-centered, hence traditional pathological observations have given insight preferentially to the development of intimal lesions/luminal loss and respectively atherosclerotic plaque vulnerability, leading to myocardial infarction, stroke, and/or lower limb ischemia. In effect, the intima has been - for more than a century - considered the most important vascular area involved in atherogenesis. As a sequela, the intima-media thickness became an accepted measure of structural arterial remodeling and a strong predictor of atherosclerosis. However, it is unlikely that such one-direction road may solely travel the whole multiplex network like that of atherogenesis. Arguably, an interactive hypothesis was proposed, which appreciated the significance of all structural components of the artery wall including PAAT $(2-4,7)$.

Nowadays, paradigms defining the cell biology of vascular diseases are the following: (i) the hypertensive vascular wall is characterized by hyperinnervation-associated medial thickening due to SMC hypertrophy/hyperplasia, whereas (ii) the atherosclerotic vascular wall is characterized by intimal thickening, medial atrophy, and adventitial and adipose remodeling including the reduced expression of perivascular nerves $(20,21)$. Of note, a significant increase in the presence of links between perivascular nerves and adventitial mast cells was demonstrated in atherosclerotic coronary vessels $(22,23)$; whether this may be the case with adipose nerves and mast cells remain to be examined.

This brief description will be followed by a story about four dots and finally by their connection resulting in triactome hypothesis in vascular biology.

\section{DOT 1}

\section{NEUROIMMUNOLOGY: NEUROTROPHINS ARE NOT SOLELY FOR NEURONS}

Life at the cellular level requires growth-promoting trophic support and immune sensing. One of the biggest recent achievements of neurobiology is the study on neurotrophic factors. The neurotrophins are exciting examples of these factors.

At the end of the nineteenth century it was envisaged by Santiago Ramon y Cajal but has not been proved that the nerves require trophic support. By a rare combination of scientific reasoning and intuition, the proof was obtained by Rita Levi-Montalcini, Viktor Hamburger, and Stanley Cohen in the early 1950s in Saint Louis, MO, USA, where the first cell growth factor, namely NGF, was discovered (24). This was embodied in a conceptual framework well known now as neurotrophic (nerve-effector interaction) theory. It reveals a pivotal role of effector (target) cells in the control of neuronal differentiation, survival and function via production of NGF, and other neurotrophic factors. Around 15 years ago, one more component, the immune cell, was incorporated into the heart of nerve-effector interactions (biactome) to become neural-immune-effector (NIE) interactions $(25,26)$. The present triactome may thus be considered a variation on general theme of NIE.

The neurotrophin family of proteins consisted of NGF, brainderived neurotrophic factor (BDNF), neurotrophin-3 (NT-3), NT4/5, NT-6, and NT-7. Neurotrophins mediate their effects via ligation of: (i) pan-neurotrophin receptor, $\mathrm{p} 75^{\mathrm{NTR}}$, and (ii) receptor tyrosine kinase (tropomyosin-related kinase) (Trk), namely, 
Table 1 | Cellular targets and sources for neurotrophins as potentially related to atherogenesis ${ }^{a}$.

\begin{tabular}{ll}
\hline Immune cells & Other cells \\
\hline Mast cells & Endothelial cells \\
Lymphocytes & Vascular smooth muscle cells \\
Macrophages & Fibroblasts/myofibroblasts \\
Dendritic cells & Platelets \\
Neutrophils & Adipocytes \\
& Perivascular nerves \\
\hline
\end{tabular}

${ }^{a}$ From Ref. (34).

TrkA (for NGF), Trk B (for BDNF and NT-4), and TrkC (for NT-3) $(27,28)$.

As often occurs, the framework of an initial concept of the physiological role of a newly discovered molecules extends in the light of emerging findings. This was also the case with NGF. During some 30 years after its discovery, there have been few reasons given to indicate that NGF acts on non-neuronal cells. Thus, it was remarkable to discover that treatment of newborn rats with NGF caused a systemic increase in the number of mast cells (29). This seminal finding paved the road of new research field, neuroimmunology $(30,31)$. Moreover, NGF and BDNF are synthesized, stored, and released not only by directly innervated cells but also by immune cells $(32,33)$ as well as other cell types (Table $\mathbf{1}$ ).

Taken together, NGF and its relative molecules are mediators of multiple biological phenomena in health and disease, ranging from the neurotrophic through immunotrophic and epitheliotrophic to metabotrophic effects. The evidence indicates that not only at neuroimmune, but also at cardiometabolic level life requires metabotrophic factors (those improving glucose, lipid, and adipokine metabolism) such as $\operatorname{NGF}$ and $\operatorname{BDNF}(35,36)$.

Furthermore, hypertension has recently been recognized as an immune disorder and accumulating evidence suggests that interactions between the sympathetic nerves, renin-angiotensin system, and immune cells play a role in blood pressure regulation $(37,38)$.

\section{DOT 2}

ADIPOIMMUNOLOGY: ADIPOSE TISSUE-ASSOCIATED IMMUNE CELLS Lymphocytes, macrophages, and mast cells

The evaluation of interactions of adipose tissue with a variety of immune cells is becoming one of the challenging topics of current biomedical research. This may elevate our knowledge about various physiological and pathological processes such as inflammation and metabolism and related disorders (34, 39-47).

White blood cells are able to home in extralymphoid peripheral tissues, including adipose tissue - here, chemokines and their receptors are critical factors in such a trafficking process, the accumulation of lymphocytes and macrophages around dying adipocytes forming "crown-like structure," a histological signature of white adipose tissue (WAT) in obesity $(45,46)$.

Mast cells were first described in 1878 by Paul Ehrlich (18541915) in his doctoral thesis "Contribution to the Theory and Practice of Histological Staining" [see Ref. (48)]. Ehrlich named these cells Mastzellen, meaning "well-fed cells," because they had high numbers of cytoplasmic granules. He observed that mast cells were commonly located in connective tissue near blood vessels and nerves, as well as in inflammatory and tumor lesions. Mast cells are phenotypically and functionally versatile effector cells that have been traditionally associated with the immunoglobulin E-mediated allergic response. However, recent studies implicate these cells in the regulation of multiple processes such as inflammation, fibrosis, angiogenesis, fibrinolysis, hemostasis, and neuroimmune interactions, which could be associated with various immune inflammatory diseases (40,49-51), hence being metaphorically dubbed master cells by Steve Galli (52). Supportively, Cromolyn and Ketotifen, two common mast cell stabilizers used in human allergic diseases, reversed pre-established obesity and diabetes in mice (53). In $o b / o b$ mice (leptin deficiency-induced obesity) compared to lean controls, adipose mast cells are distributed differentially (54). Excitingly, a genetic connection between mast cells and blood lipids was recently established (17). Data of vascular and adipose mast cells are further discussed below.

Note that pioneering findings for the importance of paracrine interactions between adipose tissue and immune cells were provided by Caroline Pond and her colleagues in the 1990s (55), thus opening a new research field, adipoimmunology.

\section{DOT 3}

\section{VASCULAR BIOLOGY: DO NOT IGNORE PERIVASCULAR NERVES AND ADVENTITIAL IMMUNE CELLS}

In 1962, Schwartz (56) wrote with respect to the presence of adventitial mononuclear cell infiltration: "It is perhaps surprising that such prominent cellular accumulation should have received so little attention. Nevertheless, since cellular infiltration of the adventitia shows such a constant relationship to the presence and degree of plaque formation, it should not be disregarded." This and other related works (56) have been largely ignored, and the atherosclerosis research for a long time has been, as mentioned above, focused on the intimal lesion (just one more example of epistemological paralysis). However, the observation that adventitial injury (including that of perivascular nerves) alone can lead to intimal thickening is an evidence for the dynamic interaction between adventitia and intima $(20,21)$; this is also the case with adiposa-media-intima interactions (see below).

\section{CORONARY RESTENOSIS}

In 1983, at the seminar organized by Dr. George Pappas (Department of Anatomy, Medical School, University of Illinois, Chicago, IL, USA), one of us (George Nikov Chaldakov) delivered a lecture entitled "The fine structure of secretory-state SMC and their possible role in occlusive arterial diseases." During the discussion, the question whether some adventitial fibroblasts may migrate to the intima was raised. The answer of the author was "I do not know. It seems impossible." However, what seemed "impossible" in 1983 was proven possible in 1996 when Shi et al. [Ref. (57), also see Ref. (58)] and Wilcox and Scott (56) summarized their results indicating that the adventitial fibroblasts proliferate and modulate their phenotype to myofibroblasts migrating to the intima of ballooninjured coronary arteries, thus contributing to the neointimal formation. Further, it was recently suggested that neoadventitial formation, consisted of fibrotic tissue and immune cells, could 
play an important role in coronary restenosis by circumferential scar-like contraction, which may cause luminal narrowing (59). These data suggest an important role of adventitial fibroblasts and immune cells, and bring into question the sole contribution of SMC to neointimal thickening in coronary restenosis.

\section{NGF, p75 ${ }^{\text {NTR }}$ AND MAST CELLS IN HUMAN CORONARY ATHEROSCLEROSIS}

In 2001, the first results about altered amount of NGF in the human coronary vascular wall affected by advanced atherosclerosis have been published [Ref. $(35,60)$, also see Ref. $(14,30$, $34,61)]$. The expression of NGF and its receptor $\mathrm{p} 75^{\mathrm{NTR}}$ in the surrounding subEAT (coronary tunica adiposa) has been examined simultaneously [Ref. $(34,60)$, also see Ref. (62)]. It was found that the reduced NGF level was accompanied by an elevated amount NGF both in subEAT and the adjacent myocardium (Figure 2). Immunohistochemical analyses of coronaries revealed that coronary vascular wall, particularly the adventitia and subEAT, expressed a stronger $\mathrm{p} 75^{\mathrm{NTR}}$ immunoreactivity in atherosclerotic compared to control arteries (60).

Since mast cells are known to be a cellular component of the coronary artery and, as indicated above, these cells not only respond to NGF action (29), but also produce and release NGF (32), the presence and distribution of mast cells in atherosclerotic and control coronaries have been also examined. In atherosclerotic vessels, mast cells (number/millimeter square) were significantly increased both in adventitia and subEAT (Figure 2). Whether these mast cell populations, via their potential to synthesize and release NGF, attempt to compensate the reduced NGF in the coronary wall, remains to further be studied.

Although "many roads lead to atheroma," the prevailing hypothesis at present is the Russell Ross' response-to-injury

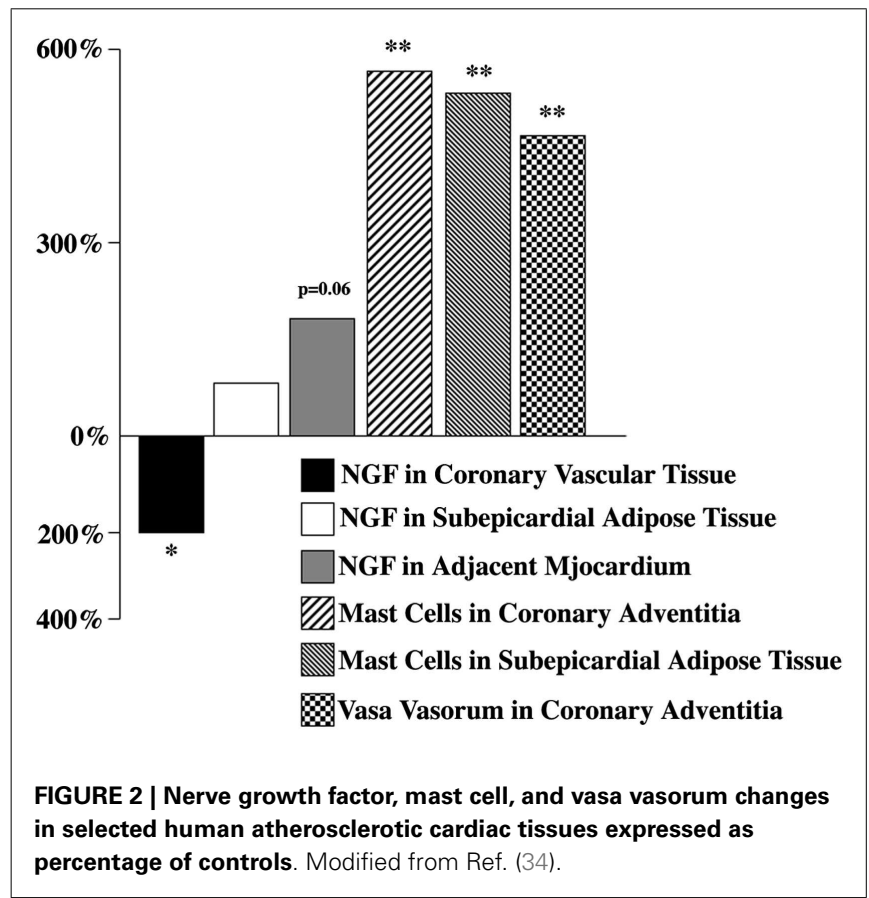

hypothesis (15), which states that atherosclerosis is an inflammatory disease that involves several aspects of wound healing. Importantly, at cell biological level wound healing may be considered one of the most remarkable conceptual contributions of Russell Ross (his pre-atherogenesis studies were namely on skin biology). Therefore one may envisage atherosclerotic intimal lesions as vascular wound. Of note, one of us (Luigi Aloe) provided clinical results of therapeutic contribution of NGF in skin and corneal wound healing (63) and thus raises a pressing question of whether this may also be the case with vascular wound, that is, the atherosclerotic plaque (15).

\section{DOT 4 \\ ADIPOBIOLOGY: WAT IS SECRETORY WHEREAS BAT THERMOGENIC ORGAN}

Accumulation of adipose tissue in the visceral and subcutaneous abdominal tissue, also around internal organs (Figure 3), is a major risk factor for the development of numerous disorders including cardiovascular and metabolic diseases. Recently, metaflammation (metabolically induced inflammation) has emerged as a pivotal process involved in the clustering of those disorders $(64,65)$.

Adipose tissue is very plastic tissue, being constantly remodeled along with weight gain and weight loss. It is a dynamic multicellular and matrix assemble composed of adipocytes, fibroblasts, immune cells, blood vessels, stem cells, and sympathetic nerve fibers $(11,12)$. There are two major subtypes of adipose tissue, WAT and brown adipose tissue (BAT).

By sending and receiving different types of protein and nonprotein signals, adipose tissue communicates with many organs in the body, including the brain, thus contributing to the control of energy, lipid, and glucose homeostasis as well as inflammation, immunity, learning, and memory among many other biological functions (10). Fat mapping (adipotopography) is an emerging biomedical field dealing with localization and amount of adipose

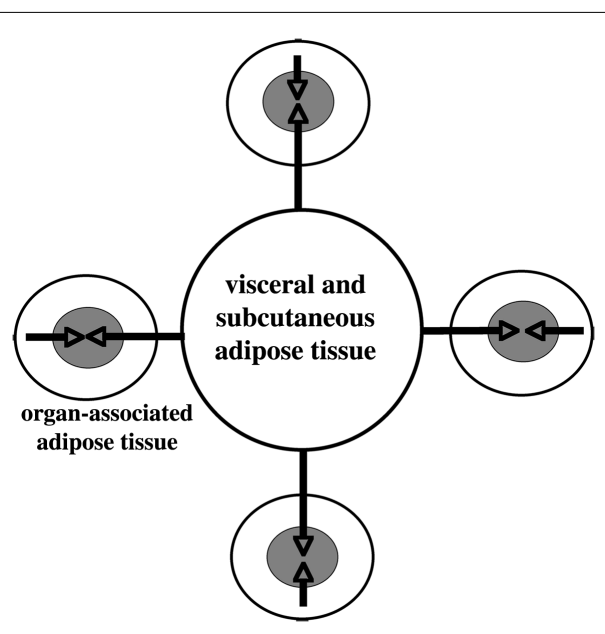

FIGURE 3 | Schematic illustration of large adipose depot (visceral and subcutaneous adipose tissue) and small adipose depots (organassociated adipose tissue). Dual action of adipokines, via endocrine pathway (long arrows) and via paracrine pathway (short arrows) on the adipose tissue-associated organs, is depicted. Modified from Ref. (66). 
tissue in the human body - fat on the outside and fat on the inside. Jeffrey Bell and colleagues (67) have scanned nearly 800 people with magnetic resonance imaging (MRI) technique, aimed at obtaining map of WAT. The authors demonstrated that as many as $45 \%$ of women and nearly $60 \%$ of men scanned have normal scores of the body mass index (BMI, $20-25 \mathrm{~kg} / \mathrm{m}^{2}$ ). These people are thin outside (TO), while actually have excessive levels of internal adipose tissue - they are fat inside (FI), hence TOFI phenotype of body fatness. Noteworthy, TOFI phenotype was also found among people who are professional models. TOFI may thus be considered a specific, "invisible" expression of Homo obesus (68) and recently introduced Homo diabesus (69).

In human body, while WAT stores energy, BAT has the ability to dissipate energy by producing heat. BAT-mediated increase in energy expenditure is realized by uncoupling respiration from ATP synthesis, via uncoupling protein 1 (UCP1), which is expressed in brown adipocytes, thus generating heat, a process known as adaptive thermogenesis $(70,71)$. Animal studies have shown that activation of BAT counteracts diet-induced weight gain and related disorders such as type 2 diabetes mellitus and metabolic syndrome $(70,71)$. Recently, the knowledge about WAT and BAT was enriched with their relatives, namely brite (brown in white) and bruscle (brown in skeletal muscle) adipocytes (72). Hence, brown adipobiology is emerging as a new challenge in biomedicine.

\section{ADIPOPARACRINOLOGY}

In 1933, Smith and Willius (73) found that "in most instances, a definite relationship between the excess of epicardial fat and the degree of general obesity occurred," suggesting a functional relationship between EAT and atherosclerosis of left anterior descending (LAD) coronary artery (73).

One of the biggest recent achievements in studying cardiometabolic diseases is associated with the "rediscovery" of an ignored tissue, the adipose tissue. Adipose tissue considered as a passive storage-releaser of lipids and heat by most cell biologists and pathologists for a long period of time, can no longer be neglected in almost any biomedical field. The last 19-20 years, that is, the time after Jeffrey Friedman's discovery of leptin, have seen it rise above the horizon to become the root cause of a plethora of syndromes and diseases $(66,74-76)$. Such an adipocentric approach has revealed that while BAT is major thermogenic organ, WAT is the body's largest endocrine and paracrine organ producing a dazzling number of adipokines, with NGF and BDNF being also produced from adipose tissue $(62,77-79)$.

Obese phenotype of WAT is featured by adipocyte hypertrophy and/or hyperplasia leading to hypoxia and invasion of immune cells, resulting in an increased production of pro-inflammatory adipokines (80). By contrast, the secretion of adiponectin, an adipokine with anti-inflammatory, anti-obesity, insulin sensitizing, and vasorelaxing, that is, metabotrophic activity $(68,69)$, is decreased in obesity and related vascular diseases (81-86).

One aspect of the role of tunica adiposa, also EAT, is whether they facilitate or inhibit the process of atherogenesis. It is know that the proximal segments of coronary arteries are surrounded by subEAT, and these are atherosclerosis-prone as compared to the distal, intramyocardial, adipose-free, and atherosclerosis-resistant coronaries $(34,73)$. However, when EAT is totally absent, as in congenital generalized lipodystrophy, coronary atherosclerosis can still occur, suggesting that a homeostatic presence of adipose tissue is required for coronary artery health, reminding the maxim "A little fat is good" or "Fatter is better?" (84). On the same vein: (i) the removal of PAAT enhances neointima formation after injury, which is attenuated by transplantation of subcutaneous adipose tissue (81), whereas (ii) the excision of LAD coronary EAT (adipectomy) decreases the progression of atherosclerosis, suggesting a positive correlation between coronary EAT and atherosclerosis (9). Obviously, there is very much more to learn about the biology of this fascinating tissue.

Whatever changes occur in tunica adiposa, little is known of whether they can be causally associated with atherogenesis or whether they are a paracrine reaction to the injury developing within other layers of the artery wall, particularly the adventitia. Given the key role of inflammation in the development of atherosclerotic lesions, what role might then adiposa play in the process of atherogenesis? As indicated above, the expansion of adipose tissue seen in obesity is associated with adipose inflammation leading to an imbalanced secretion including: (i) an enhanced release of pro-inflammatory adipokines, and (ii) a decreased release of antiinflammatory (metabotrophic) adipokines (Table 2) as well as (iii) a disbalance in contractile and relaxing factors released from adiposa (Table 3). Such a yin-and-yang pattern of cell secretion requires a research aiming at: (i) the inhibition of secretion and/or receptor sensitivity of pro-inflammatory and vasocontractile

Table 2 | Selected list of pro- and anti-inflammatory adipose-derived signals relevant to cardiovascular disease.

\begin{tabular}{ll}
\hline Pro-inflammatory signals & Anti-inflammatory signals \\
\hline Tumor necrosis factor- $\alpha$ & Adiponectin \\
Interleukin-1 $\beta,-18$ /inflammasome & Interleukin-10 \\
Hypoxia-inducible factor $1 \alpha$ & Nerve growth factor \\
MIP-1 (CCL2) & Interleukin-1 receptor antagonist \\
Leptin & Brain-derived neurotrophic factor \\
RANTES (CCL5) & Humanin ${ }^{a}$ \\
Fractalkine (CX3CL1) & Irisin \\
Interleukin-8 (CXCL8) & Apelin, Otopetrin 1 \\
Resistin & Omentin, Chemerin \\
ROS & Resolvin D1
\end{tabular}

Acylation stimulating protein

Netrin-1

Profilin-1

${ }^{a}$ Humanin is not (yet) adipose-derived product; it is a peptide produced by mitochondria (89).

MIP-1 (CCL2), monocyte chemoattractant protein (CCL2, cysteine-cysteine modified chemokine ligand 2); RANTES, regulated on activated normalT cell expressed and secreted; ROS, reactive oxygen species.

For references see the text, also Ref. (89-108). Connecting references 163, 92, 93), NGF might be implicated in the therapy of atherosclerotic lesion viewed as vascular wound (15). 
Table 3 | Adipose tissue-derived mediators controlling vascular tone ${ }^{a}$.

\section{Vasodilators}

Nitric oxide (NO), adipocyte-derived relaxing factor, hydrogen sulfide $\left(\mathrm{H}_{2} \mathrm{~S}\right)$, adiponectin, cardiac natriuretic peptide, adrenomedullin, visfatin, omentin Vasoconstrictors

Superoxide anion, angiotensin II, endothelin-1, tumor necrosis factor- $\alpha$

${ }^{a}$ All components of renin-angiotensin system are also expressed in periadventitial adipose tissue, suggesting their paracrine involvement in the pathogenesis of atherosclerosis and hypertension $(37,87)$. Whether adipose-derived contractile mediators may contribute to the so-called "adventitial shrinkage" due to myofibroblast contraction in postangioplasty coronary restenosis (59), remains to be studied. For other mediators see Ref. (109-118).

adipose-derived mediators, and (ii) the stimulation of secretion and/or receptor sensitivity of anti-inflammatory (metabotrophic) and vasorelaxing adipose-derived mediators $(87,88)$.

Arguably, adipoparacrine activity is increasingly implicated in the pathogenesis of CVD. "So what does it mean if" (119) adipoparacrinology (10) and adipoimmunology (74) are indeed a biological rationale in vascular biology? First, in basic research, we should no longer disregard adventitia and adiposa, but preserve them in place and subject to a thorough examination; in other words, we need to keep open minds on all vascular coats. Second, echocardiography, computer tomography, MRI, and other non-invasive imaging of heart- and artery-associated adipose tissue may identify high-risk population susceptible to CVD (120, 121). Third, "non-touch harvesting technique" is an example of appreciation of adipoparacrinology in coronary artery bypass surgery $(109,110)$. Fourth, tunica adipose like adventitia (59) may represent a new target for in situ therapeutic applications.

\section{CONNECTING THE DOTS: VASCULAR TRIACTOME}

A central aim of neuroadipoimmunology is to map molecular interactions, in order to learn how they account for cardiovascular and metabolic biology and how alterations in them lead to disorders, including atherosclerosis and hypertension. However, until now we have paid less attention to the possible interactive talk in the vascular wall. When connecting the dots described above we may better understand which are the mediators in the suggested interactions between perivascular nerves, adventitial/adipose immune cells, and paracrine adipose tissue, herein designated vascular triactome. As indicated in Tables 2 and 3, the adipose-derived signaling molecules might be among the major players in the triactome. In effect, we may integrate the traditional "inside-out" (intimal) to an "outside-in" (adventitial and adipose) pathway in the pathogenesis of CVD. The present hypothesis may thus provide new insights into the therapy of these diseases.

That's it. No big deal. Just a triactome (Figure 1). The future challenge is therefore to cultivate integrative thinking about how we can make triactome work for the benefit of cardiometabolic health.

\section{ACKNOWLEDGMENTS}

None of this review would have been possible without the staunch support and creative collaboration over the years of our brainand-heart friends (BHF) Anna Kadar, Yasuo Uehara, Yukio Yamori,
Takashi Fujiwara, Anton B. Tonchev, Francesco Angelucci, Federica Sornelli, Mariyana G. Hristova, Vesselka Nikolova, Stanislav Yanev, and many other too numerous to name. We apologize to the authors of many relevant articles that were not quoted here for reasons of brevity.

\section{REFERENCES}

1. Soltis EE, Cassis LA. Influence of perivascular adipose tissue on rat aortic smooth muscle responsiveness. Clin Exp Hypertens (1991) A13: 277-96.

2. Chaldakov GN, Fiore M, Ghenev PI, Stankulov IS, Aloe L. Atherosclerotic lesions: possible interactive involvement of intima, adventitia and associated adipose tissue. Int Med J (2000) 7:43-9.

3. Chaldakov GN, Fiore M, Ghenev PI, Stankulov IS, Angelucci F, Pavlov PS, et al. Conceptual novelties in atherogenesis: smooth muscle cells, adventitia, and adipose tissue. Biomed Rev (2000) 11:63-7. doi:10.14748/bmr.v11.131

4. Chaldakov GN, Stankulov IS, Aloe L. Subepicardial adipose tissue in human coronary atherosclerosis: another neglected phenomenon. Atherosclerosis (2001) 154:237-8. doi:10.1016/S0021-9150(00)00676-6

5. Gollasch M, Dubrovska G. Paracrine role for periadventitial adipose tissue in the regulation of arterial tone. Trends Pharmacol Sci (2004) 25:647-53. doi:10.1016/j.tips.2004.10.005

6. Yudkin JS, Eringa E, Stehouwer CDA. "Vasocrine" signalling from perivascular fat: a mechanism linking insulin resistance to vascular disease. Lancet (2005) 365:1817-20. doi:10.1016/S0140-6736(05)66585-3

7. Chaldakov GN, Tonchev AB, Stankulov IS, Ghenev PI, Fiore M, Aloe L, et al. Periadventitial adipose tissue (tunica adiposa): enemy or friend around? Arch Pathol Lab Med (2007) 131:1766.

8. Verhagen SN, Buijsrogge MP, Vink A, van Herwerden LA, van der Graaf Y, Vissseren FL. Secretion of adipocytokines by perivascular adipose tissue near stenotic and non-stenotic coronary artery segments in patients undergoing CABG. Atherosclerosis (2014) 233:242-7. doi:10.1016/j.atherosclerosis.2013. 12.005

9. McKenney ML, Schultz KA, Boyd JH, Byrd JP, Alloosh M, Teague SD, et al. Epicardial adipose excision slows the progression of porcine coronary atherosclerosis. J Cardiothorac Surg (2014) 9:2-11. doi:10.1186/1749-8090-9-2

10. Chaldakov GN, Tunçel N, Beltowski J, Fiore M, Rancic G, Tonchev A, et al. Adipoparacrinology: an emerging field in biomedical research. Balkan Med J (2012) 29:2-9. doi:10.5152/balkanmedj.2012.022

11. Bulloch JM, Daly CJ. Autonomic nerves and perivascular fat: interactive mechanisms. Pharmacol Ther (2014). doi:10.1016/j.pharmthera.2014.02.005

12. Vaughan $\mathrm{CH}$, Zarebidaki E, Ehlen JC, Bartness TJ. Analysis and measurement of the sympathetic and sensory innervation of white and brown adipose tissue. Methods Enzymol (2014) 537:199-225. doi:10.1016/B978-0-12-4116191.00011-2

13. Chaldakov GN, Vankov VN. Morphological aspects of secretion in the arterial smooth muscle cell, with special reference to the Golgi complex and microtubular cytoskeleton. Atherosclerosis (1986) 61:175-92. doi:10.1016/0021-9150(86) 90137-1

14. Chaldakov GN. Cardiovascular adipobiology: a novel. Heart-associated adipose tissue in cardiovascular disease. Ser J Exp Clin Res (2008) 9:81-8.

15. Ross R. Mechanisms of disease: atherosclerosis - an inflammatory disease. N Engl J Med (1999) 340:115-26. doi:10.1056/NEJM199901143400207

16. Geng Y-J, Jonasson L. Linking immunity to atherosclerosis: implications for vascular pharmacology - a tribute to Göran K. Hansson. Vascul Pharmacol (2012) 56:29-33. doi:10.1016/j.vph.2011.11.001

17. Inouye M, Silander K, Hamalainen E, Salomaa V, Harald K, Jousilahti P, et al. An immune response network associated with blood lipid levels. PLoS Genet (2010) 6:e1001113. doi:10.1371/journal.pgen.1001113

18. Hilgendorf I, Theurl I, Gerhardt LM, Robbins CS, Weber GF, Gonen A, et al. Innate response activator B cells aggravate atherosclerosis by stimulating $\mathrm{TH} 1$ adaptive immunity. Circulation (2014). doi:10.1161/CIRCULATIONAHA.113. 006381

19. Tang YL, Yang YZ, Wang S, Huang T, Tang CK, Xu ZX, et al. Mast cell degranulator compound 48-80 promotes atherosclerotic plaque in apolipoprotein $\mathrm{E}$ knockout mice with perivascular common carotid collar placement. Chin Med J (2009) 122:319-25. 
20. Booth RFC, Martin JF, Honey AC, Hassall DG, Beesley JE, Moncada S. Rapid development of atherosclerotic lesions in the rabbit carotid artery induced by perivascular manipulation. Atherosclerosis (1989) 76:257-68. doi:10.1016/ 0021-9150(89)90109-3

21. Scott TM, Honey AC, Martin JF, Booth RF. Perivascular innervation is lost in experimental atherosclerosis. Cardioscience (1992) 3:145-53.

22. Laine P, Naukkarinen A, Heikkila L, Penttila A, Kovanen PT. Adventitial mast cells connect with sensory nerve fibers in atherosclerotic coronary arteries. Circulation (2000) 101:1665-9. doi:10.1161/01.CIR.101.14.1665

23. Bot I, de Jager SC, Bot M, van Heiningen SH, de Groot P, Veldhuizen RW, et al. The neuropeptide substance $P$ mediates adventitial mast cell activation and induces intraplaque hemorrhage in advanced atherosclerosis. Circ Res (2010) 106:89-92. doi:10.1161/CIRCRESAHA.109.204875

24. Levi-Montalcini R. The nerve growth factors 35 years later. Science (1987) 237:1154-62. doi:10.1126/science.3306916

25. Chaldakov GN, Ghenev PI, Andonov M, Valchanov K, Tonchev A, Pancheva R. Neural-immune-effector (NIE) cross-talk in vascular trophobiology: proposal for new and not yet exploited purinergic regulatory mechanisms. Biomed Rev (1994) 3:81-6. doi:10.14748/bmr.v3.205

26. Chaldakov G. Neural-immune-effector trophic interaction: an emerging concept for the neurotrophic theory [abstract]. Folia Anat (1996) 24(Suppl 2):24.

27. Azoulay D, Urshansky N, Karni A. Low and dysregulated BDNF secretion from immune cells of MS patients is related to reduced neuroprotection. J Neuroimmunol (2008) 195:186-93. doi:10.1016/j.jneuroim.2008.01.010

28. Fiore M, Chaldakov GN, Aloe L. Nerve growth factor as a signaling molecule for nerve cells and also for the neuroendocrine-immune systems. Rev Neurosci (2009) 20:133-45. doi:10.1515/REVNEURO.2009.20.2.133

29. Aloe L, Levi-Montalcini R. Mast cells increase in tissues of neonatal rats injected with the nerve growth factor. Brain Res (1977) 133:358-66. doi:10.1016/00068993(77)90772-7

30. Hasan W, Jama A, Donohue T, Wernli G, Onyszchuk G, Al-Hafez B, et al. Sympathetic hyperinnervation and inflammatory cell NGF synthesis following myocardial infarction in rats. Brain Res (2006) 1124:142-54. doi:10.1016/ j.brainres.2006.09.054

31. Bracci-Laudiero L, Aloe L, Caroleao MC, Buanne P, Costa N, Starace G, et al. Endogenous NGF regulates CGRP expression in human monocytes, and affects HLA-DR and CD86 expression and IL-10 production. Blood (2005) 106:3507-14. doi:10.1182/blood-2004-10-4055

32. Leon A, Buriani A, Dal Toso R, Fabris M, Romanello S, Aloe L, et al. Mast cells synthesize, store, and release nerve growth factor. Proc Natl Acad Sci U S A (1994) 91:3739-43. doi:10.1073/pnas.91.9.3739

33. Wernli G, Hasan W, Bhattacherjee A, van Rooijen N, Smith PG. Macrophage depletion suppresses sympathetic hyperinnervation following myocardial infarction. Basic Res Cardiol (2009) 104:681-93. doi:10.1007/s00395-0090033-3

34. Chaldakov GN, Fiore M, Stankulov IS, Manni L, Hristova MG, Antonelli A, et al. Neurotrophin presence in human coronary atherosclerosis and metabolic syndrome: a role for NGF and BDNF in cardiovascular disease? Prog Brain Res (2004) 146:279-89. doi:10.1016/S0079-6123(03)46018-4

35. Chaldakov GN, Fiore M, Stankulov IS, Hristova M, Antonelli A, Manni L, et al. NGF, BDNF, leptin, and mast cells in human coronary atherosclerosis and metabolic syndrome. Arch Physiol Biochem (2001) 109:357-60. doi:10.1076/apab.109.3.357.9353

36. Navarro-Tableros V, Fiordelisio T, Hernandez-Cruz A, Hiriart M. Nerve growth factor promotes development of glucose-induced insulin secretion in rat neonate pancreatic beta cells by modulating calcium channels. Channels (Austin) (2007) 1:408-16. doi:10.4161/chan.1.6.5450

37. Cuzik TJ, Hoch NE, Brown KA, McCann LA, Rahman A, Dikalov S, et al. Role of the $\mathrm{T}$ cell in the genesis of angiotensin II induced hypertension and vascular dysfunction. J Exp Med (2007) 204:2449-60. doi:10.1084/jem.20070657

38. de Kloet AD, Krause EG, Shi PD, Zubcevic J, Raizada MK, Sumners C. Neuroimmune communication in hypertension and obesity: a new therapeutic angle? Pharmacol Ther (2013) 138:428-40. doi:10.1016/j.pharmthera.2013.02.005

39. Kasselman LJ, Sideris A, Bruno C, Perez WR, Cai N, Nicoletti JN, et al. BDNF: a missing link between sympathetic dysfunction and inflammatory disease? J Neuroimmunol (2006) 175:118-27. doi:10.1016/j.jneuroim.2006.03.008
40. Divoux A, Moutel S, Poitou C, Lacasa D, Veyrie N, Aissat A, et al. Mast cells in human adipose tissue: link with morbid obesity, inflammatory status, and diabetes. J Clin Endocrinol Metab (2012) 97:E1677-85. doi:10.1210/jc.2012-1532

41. Pucino V, De Rosa V, Procaccini C, Matarese G. Regulatory T cells, leptin and angiogenesis. Chem Immunol Allergy (2014) 99:155-69. doi:10.1159/ 000353557

42. Jin C, Flavell RA. Innate sensors of pathogen and stress: linking inflammation to obesity. J Allergy Clin Immunol (2013) 132:287-94. doi:10.1016/j.jaci.2013. 06.022

43. Winer DA, Winer S, Chang MH, Shen L, Engleman EGB. Lymphocytes in obesity-related adipose tissue inflammation and insulin resistance. Cell $\mathrm{Mol}$ Life Sci (2014) 71:1033-43. doi:10.1007/s00018-013-1486-y

44. O'Rourke RW, Gaston GD, Meyer KA, White AE, Marks DL. Adipose tissue NK cells manifest an activated phenotype in human obesity. Metabolism (2013) 62:1557-61. doi:10.1016/j.metabol.2013.07.011

45. Makki K, Froguel P, Wolowczuk I. Adipose tissue in obesity-related inflammation and insulin resistance: cells, cytokines, and chemokines. ISRN Inflamm (2013) 2013:139239. doi:10.1155/2013/139239

46. Boumié A, Casteilla L, Lafontan M. Adipose tissue lymphocytes and macrophages in obesity and insulin resistance: makers or markers, and which comes first? Arterioscler Thromb Vasc Biol (2008) 28:1211-3. doi:10.1161/ ATVBAHA.108.168229

47. Priceman SJ, Kujawski M, Shen S, Cherryholmes GA, Lee H, Zhang C, et al. Regulation of adipose tissue $\mathrm{T}$ cell subsets by Stat 3 is crucial for diet-induced obesity and insulin resistance. Proc Natl Acad Sci U S A (2013) 110:13079-84. doi:10.1073/pnas.1311557110

48. Vyas H, Krishnaswamy G. Paul Ehrlich's "Mastzellen" - from aniline dyes to DNA chip arrays: a historical review of developments in mast cell research. Methods Mol Biol (2006) 315:3-11.

49. Bot I, Biessen EAL. Mast cells in atherosclerosis. Thromb Haemost (2011) 106:820-6. doi:10.1160/TH11-05-0291

50. Lee BC, Lee J. Cellular and molecular players in adipose tissue inflammation in the development of obesity-induced insulin resistance. Biochim Biophys Acta (2014) 1842:446-62. doi:10.1016/j.bbadis.2013.05.017

51. Shi MA, Shi GP. Different roles of mast cells in obesity and diabetes: lessons from experimental animals and humans. Front Immunol (2012) 25(3):7. doi:10.3389/fimmu.2012.00007

52. Galli SJ, Tsai M. Mast cells: versatile regulators of inflammation, tissue remodeling, host defense and homeostasis. J Dermatol Sci (2008) 49:7-19. doi:10.1016/j.jdermsci.2007.09.009

53. Zhang J, Shi G-P. Masts cells and metabolic syndrome. Biochim Biophys Acta (2012) 1822:14-20. doi:10.1016/j.bbadis.2010.12.012

54. Altintas MM, Nayer B, Walford EC, Johnson KB, Gaidosh G, Reiser J, et al. Leptin deficiency-induced obesity affects the density of mast cells in abdominal fat depots and lymph nodes in mice. Lipids Health Dis (2012) 11:21. doi:10.1186/1476-511X-11-21

55. Pond CM. Adipose tissue and the immune system. Prostaglandins Leukot Essent Fatty Acids (2005) 73:17-30. doi:10.1016/j.plefa.2005.04.005

56. Wilcox JN, Scott NA. Potential role of the adventitia in arteritis and atherosclerosis. Int J Cardiol (1996) 54(Suppl):S21-35. doi:10.1016/S0167-5273(96) 02811-2

57. Shi Y, O’Brien JE, Fard A, Mannion JD, Wang D, Zalewski A. Adventitial myofibroblasts contribute to neointimal formation in injured porcine coronary arteries. Circulation (1996) 94:1655-64. doi:10.1161/01.CIR.94.7.1655

58. Ghenev PI, Chaldakov GN. Neural-immune links in adventitial remodeling in human coronary atherosclerosis. Circulation (1997) 96:2083-4.

59. Huehns TY, Gonschior P, Hofling B. Adventitia as a target for intravascular local drug delivery. Heart (1996) 75:537-8. doi:10.1136/hrt.75.6.537

60. Chaldakov GN, Stankulov IS, Fiore M, Ghenev PI, Aloe L. Nerve growth factor levels and mast cell distribution in human coronary atherosclerosis. Atherosclerosis (2001) 159:57-66. doi:10.1016/S0021-9150(01)00488-9

61. Hasan W, Smith PG. Decreased adrenoceptor stimulation in heart failure rats reduces NGF expression by cardiac parasympathetic neurons. Auton Neurosci (2014) 181:13-20. doi:10.1016/j.autneu.2013.11.001

62. Romo-Yáñez J, Velasco M, Larqué C, Chávez-Maldonado JP, Hiriart M. Differential expression of NGF and BDNF in rat adipose depots during early development and adulthood. Adipobiology (2013) 5:39-43. 
63. Aloe L, Tirassa P, Lambiase A. The topical application of nerve growth factor as a pharmacological tool for human corneal and skin ulcers. Pharmacol Res (2008) 57:253-8. doi:10.1016/j.phrs.2008.01.010

64. Hotamisligil GS. Inflammation and metabolic disorders. Nature (2006) 444:860-7. doi:10.1038/nature05485

65. Dali-Youcef N, Mecili M, Ricci R, Andrès E. Metabolic inflammation: connecting obesity and insulin resistance. Ann Med (2013) 45:242-53. doi:10.3109/ 07853890.2012.705015

66. Chaldakov GN, Stankulov IS, Hristova M, Ghenev PI. Adipobiology of disease: adipokines and adipokine-targeted pharmacology. Curr Pharm Des (2003) 9:1023-31. doi:10.2174/1381612033455152

67. Louise TE, Saeed N, Hajnal JV, Brynes A, Goldstone AP, Frost G, et al. Magnetic resonance imaging of total body fat. J Appl Physiol (1998) 85: 1778-85.

68. Chaldakov GN, Fiore M, Tonchev AB, Dimitrov D, Pancheva R, Rancic G, et al. Homo obesus: a metabotrophin-deficient species. Pharmacology and nutrition insight. Curr Pharm Des (2007) 13:2176-9. doi:10.2174/ 138161207781039616

69. Aloe L, Tonchev AB, Fiore M, Chaldakov GN. Homo diabesus: involvement of metabotrophic factors. Adipobiology (2013) 5:45-9.

70. Sacks H, Symonds ME. Anatomical locations of human brown adipose tissue functional relevance and implications in obesity and type 2 diabetes. Diabetes (2013) 62:1783-90. doi:10.2337/db12-1430

71. Chechi K, Nedergaard J, Richard D. Brown adipose tissue as an anti-obesity tissue in humans. Obes Rev (2014) 15:92-106. doi:10.1111/obr.12116

72. Giralt M, Villarrova F. White, brown, beige/brite: different adipose cells for different functions? Endocrinology (2013) 154:2992-3000. doi:10.1210/en.20131403

73. Marchington JM, Mattacks CA, Pond CM. Adipose tissue in the mammalian heart and pericardium: structure, foetal development and biochemical properties. Comp Biochem Physiol B (1989) 94:225-32.

74. Poursharifi P, Lapointe M, Pétrin D, Devost D, Gauvreau D, Hébert TE, et al. C5L2 and C5aR interaction in adipocytes and macrophages: insights into adipoimmunology. Cell Signal (2013) 25:910-9. doi:10.1016/j.cellsig.2012. 12.010

75. Chaldakov GN, Fiore M, Tonchev AB, Aloe L. Neuroadipology: a novel component of neuroendocrinology. Cell Biol Int (2010) 34:1051-3. doi:10.1042/ CBI20100509

76. Renes J, Mariman E. Application of proteomics technology in adipocyte biology. Mol Biosyst (2013) 9:1076-91. doi:10.1039/c3mb25596d

77. Hausman GJ, Barb CR, Dean RG. Patterns of gene expression in pig adipose tissue: insulin-like growth factor system proteins, neuropeptide Y (NPY), NPY receptors, neurotrophic factors and other secreted factors. Domest Anim Endocrinol (2008) 35:24-34. doi:10.1016/j.domaniend.2008.01.004

78. Sornelli F, Fiore M, Chaldakov GN, Aloe L. Adipose tissue-derived nerve growth factor and brain-derived neurotrophic factor: results from experimental stress and diabetes. Gen Physiol Biophys (2009) 28:179-83.

79. Ryan VH, German AJ, Wood IS, Hunter L, Morris P, Trayhurn P. NGF gene expression and secretion by canine adipocytes in primary culture: upregulation by the inflammatory mediators LPS and TNFalpha. Horm Metab Res (2008) 40:861-8. doi:10.1055/s-0028-1083782

80. Trayhurn P, de Heredia FP, Wang B, de Oliveira C, González-Muniesa P, Wood SI. Cellular hypoxia: a key modulator of adipocyte function in obesity? Adipobiology (2009) 1:19-26. doi:10.1038/ijo.2011.279

81. Takaoka M, Nagata D, Kihara S, Shimomura I, Kimura Y, Tabata Y, et al. Periadventitial adipose tissue plays a critical role in vascular remodeling. Circ Res (2009) 105:906-11. doi:10.1161/CIRCRESAHA.109.199653

82. Nakamura K, Fuster JJ, Walsh K. Adipokines: a link between obesity and cardiovascular disease. J Cardiol (2013). doi:10.1016/j.jjcc.2013.11.006

83. Almabrouk TA, Ewart MA, Salt IP, Kennedy S. Perivascular fat, AMP-activated protein kinase and vascular diseases. Br J Pharmacol (2014) 171:595-617. doi:10.1111/bph.12479

84. Brandes RP. The fatter the better? Perivascular adipose tissue attenuates vascular contraction through different mechanisms. Br J Pharmacol (2007) 151:303-4. doi:10.1038/sj.bjp.0707229

85. Spiroglou SG, Kostopoulos CG, Varakis JN, Papadaki HH. Adipokines in periaortic and epicardial adipose tissue: differential expression and relation to atherosclerosis. JAtheroscler Thromb (2010) 17:115-30. doi:10.5551/ jat. 1735
86. Rossi C, Santini E, Chiarugi M, Salvati A, Comassi M, Vitolo E, et al. The complex P2X7 receptor/inflammasome in perivascular fat tissue of heavy smokers. Eur J Clin Invest (2014) 44:295-302. doi:10.1111/eci.12232

87. Lu C, Su LY, Lee RM, Gao YJ. Mechanisms for perivascular adipose tissuemediated potentiation of vascular contraction to perivascular neuronal stimulation: the role of adipocyte-derived angiotensin II. Eur J Pharmacol (2010) 634:107-12. doi:10.1016/j.ejphar.2010.02.006

88. Yanev S, Aloe L, Fiore F, Chaldakov GN. Neurotrophic and metabotrophic potential of nerve growth factor and brain-derived neurotrophic factor: linking cardiometabolic and neuropsychiatric diseases. World J Pharmacol (2013) 2:92-9. doi:10.5497/wjp.v2.i4.92

89. Hoang PT, Park P, Cobb LJ, Paharkova-Vatchkova V, Hakimi M, Cohen P, et al. The neurosurvival factor Humanin inhibits beta-cell apoptosis via signal transducer and activator of transcription 3 activation and delays and ameliorates diabetes in nonobese diabetic mice. Metabolism (2010) 59:343-9. doi:10.1016/j.metabol.2009.08.001

90. Tack CJ, Stienstra R, Joosten LA, Netea MG. Inflammation links excess fat to insulin resistance: the role of the interleukin-1 family. Immunol Rev (2012) 249:239-52. doi:10.1111/j.1600-065X.2012.01145.x

91. Gomez-Pinilla F, Vaynman S, Ying Z. Brain-derived neurotrophic factor functions as a metabotrophin to mediate the effects of exercise on cognition. Eur J Neurosci (2008) 28:2278-87. doi:10.1111/j.1460-9568.2008.06524.x

92. Cushing P, Bhalla R, Johnson AM, Rushlow WJ, Meakin SO, Belliveau DJ. Nerve growth factor increases connexin 43 phosphorylation and gap junctional intercellular communication. J Neurosci Res (2005) 82:788-801. doi:10.1002/jnr. 20689

93. Becker DL, Thrasivoulou C, Phillips AR. Connexins in wound healing; perspectives in diabetic patients. Biochim Biophys Acta (2012) 1818:2068-75. doi:10.1016/j.bbamem.2011.11.017

94. Novelle MG, Contreras C, Romero-Picó A, López M, Diéguez C. Irisin, two years later. Int J Endocrinol (2013) 2013:746281. doi:10.1155/2013/746281

95. Iacobellis G, Di Gioia C, Petramala L, Chiappetta C, Serra V, Zinnamosca $\mathrm{L}$, et al. Brown fat expresses adiponectin in humans. Int J Endocrinol (2013) 2013:126751. doi:10.1155/2013/126751

96. Tan BK, Adya R, Randeva HS. Omentin: a novel link between inflammation, diabesity, and cardiovascular disease. Trends Cardiovasc Med (2010) 20:143-8. doi:10.1016/j.tcm.2010.12.002

97. Castan-Laurell I, Dray C, Attané C, Duparc T, Knauf C, Valet P. Apelin, diabetes, and obesity. Endocrine (2011) 40:1-9. doi:10.1007/s12020-011-9507-9

98. Wang GX, Cho KW, Uhm M, Hu CR, Li S, Cozacov Z, et al. Otopetrin 1 protects mice from obesity-associated metabolic dysfunction through attenuating adipose tissue inflammation. Diabetes (2013). doi:10.2337/db13-1139

99. Hellmann J, Tang Y, Kosuri M, Bhatnagar A, Spite M. Resolvin D1 decreases adipose tissue macrophage accumulation and improves insulin sensitivity in obese-diabetic mice. FASEB J (2011) 25:2399-407. doi:10.1096/fj.10-178657

100. Benomar Y, Gertler A, De Lacy P, Crépin D, Ould Hamouda H, Riffault L, et al. Central resistin overexpression induces insulin resistance through tolllike receptor 4. Diabetes (2013) 62:102-14. doi:10.2337/db12-0237

101. Govoni S, Pascale A, Amadio M, Calvillo L, D'Elia E, Cereda C, et al. NGF and heart: is there a role in heart disease? Pharmacol Res (2011) 63:266-77. doi:10.1016/j.phrs.2010.12.017

102. Asanome A, Kawabe J, Matsuki M, Kabara M, Hira Y, Bochimoto H, et al. Nerve growth factor stimulates regeneration of perivascular nerve, and induces the maturation of microvessels around the injured artery. Biochem Biophys Res Commun (2014) 443:150-5. doi:10.1016/j.bbrc.2013.11.070

103. Prencipe G, Minnone G, Strippoli R, De Pasquale L, Petrini S, Caiello I, et al. Nerve growth factor downregulates inflammatory response in human monocytes through TrkA. J Immunol (2014). doi:10.4049/jimmunol. 1300825

104. Fruhbeck G, Becerril S, Sáinz N, Garrastachu P, Garcia-Velloso MJ. BAT: a new target for human obesity. Trends Pharmacol Sci (2009) 30:387-96. doi:10.1016/j.tips.2009.05.003

105. Poursharifi P, Rezvani R, Gupta A, Lapointe M, Marceau P, Tchernof A, et al. Association of immune and metabolic receptors C5aR and C5L2 with adiposity in women. Mediators Inflamm (2014) 2014:413921. doi:10.1155/ 2014/413921

106. Ramkhelawon B, Hennessy EJ, Ménager M, Ray TD, Sheedy FJ, Hutchison S. Netrin-1 promotes adipose tissue macrophage retention and insulin resistance in obesity. Nat Med (2014). doi:10.1038/nm.3467 
107. Bongo JB, Peng DQ. The neuroimmune guidance cue netrin-1: a new therapeutic target in cardiovascular disease. J Cardiol (2014) 63:95-8. doi:10.1016/ j.jjcc.2013.10.006

108. Pae M, Romeo GR. The multifaceted role of profilin- 1 in adipose tissue inflammation and glucose homeostasis. Adipocyte (2014) 3:69-74. doi:10.4161/adip. 26965

109. Dashwood MR, Dooley A, Shi-Wen X, Abraham DJ, Souza DS. Does periadventitial fat-derived nitric oxide play a role in improved saphenous vein graft patency in patients undergoing coronary artery bypass surgery? J Vasc Res (2007) 44:175-81. doi:10.1159/000099833

110. Malinowski M, Deja MA, Golba KS, Roleder T, Biernat J, Wos S. Perivascular tissue of internal thoracic artery releases potent nitric oxide and prostacyclinindependent anticontractile factor. Eur J Cardiothorac Surg (2008) 33:225-31. doi:10.1016/j.ejcts.2007.11.007

111. Fesüs G, Dubrovska G, Gorzelniak K, Kluge R, Huang Y, Luft FC, et al. Adiponectin is a novel humoral vasodilator. Cardiovasc Res (2007) 75:719-27. doi:10.1016/j.cardiores.2007.05.025

112. Gao YJ, Takemori K, Su LY, An WS, Lu C, Sharma AM, et al. Perivascular adipose tissue promotes vasoconstriction: the role of superoxide anion. Cardiovasc Res (2006) 71:363-73. doi:10.1016/j.cardiores.2006.03.013

113. Tunçel N, Peker E, Sener E, Dal AG, Tunçel M, Chaldakov GN, et al. Cold exposure and adipose nitric oxide and mast cells: influence on aorta contractility. Adipobiology (2009) 1:67-75. doi:10.14748/adipo.v1.251

114. Wojcicka G, Jamroz-Wisniewska A, Attanasova P, Chaldakov GN, ChylinskaKula B, Beltowski J. Differential effects of statins on endogenous $\mathrm{H}_{2} \mathrm{~S}$ formation in perivascular adipose tissue. Pharmacol Res (2011) 63:68-76. doi:10.1016/j. phrs.2010.10.011

115. Yamawaki H, Hara N, Okada M, Hara Y. Visfatin causes endotheliumdependent relaxation in isolated blood vessels. Biochem Biophyis Res Commun (2009) 383:503-8. doi:10.1016/j.bbrc.2009.04.074

116. Miao CY, Li ZY. The role of perivascular adipose tissue in vascular smooth muscle cell growth. Br J Pharmacol (2012) 165:643-58. doi:10.1111/j.14765381.2011.01404.x
117. Yamawaki H, Tsubaki N, Mukohda M, Okada M, Hara Y. Omentin, a novel adipokine, induces vasodilation in rat isolated blood vessels. Biochem Biophyis Res Commun (2010) 393:668-72. doi:10.1016/j.bbrc.2010.02.053

118. Oriowo MA. Perivascular adipose tissue, vascular reactivity and hypertension. Med Princ Pract (2014). doi:10.1159/000356380

119. Sacks HS. Weight loss in obesity reduces epicardial fat thickness; so what? JAppl Physiol (2009) 106:1-2. doi:10.1152/japplphysiol.91396.2008

120. Skilton MR, Sérusclat A, Sethu AH, Brun S, Bernard S, Balkau B, et al. Noninvasive measurement of carotid extra-media thickness: associations with cardiovascular risk factors and intima-media thickness. JACC Cardiovasc Imaging (2009) 2:176-82. doi:10.1016/j.jcmg.2008.09.013

121. Schlett CL, Hoffmann U. Identification and quantification of fat compartments with CT and MRI and their importance. Radiologe (2011) 51:372-8. doi:10.1007/s00117-010-2088-4

Conflict of Interest Statement: The authors declare that the research was conducted in the absence of any commercial or financial relationships that could be construed as a potential conflict of interest.

Received: 11 February 2014; accepted: 14 March 2014; published online: 08 April 2014. Citation: Chaldakov GN, Fiore M, Ghenev PI, Beltowski J, Ranćić G, Tunçel N and Aloe L (2014) Triactome: neuro-immune-adipose interactions. Implication in vascular biology. Front. Immunol. 5:130. doi: 10.3389/fimmu.2014.00130

This article was submitted to Inflammation, a section of the journal Frontiers in Immunology.

Copyright (C) 2014 Chaldakov, Fiore, Ghenev, Beltowski, Ranćić, Tunçel and Aloe. This is an open-access article distributed under the terms of the Creative Commons Attribution License (CC BY). The use, distribution or reproduction in other forums is permitted, provided the original author(s) or licensor are credited and that the original publication in this journal is cited, in accordance with accepted academic practice. No use, distribution or reproduction is permitted which does not comply with these terms. 